\title{
Egy kérészéletü köztársaság: 1918. december 5-6.
}

\author{
Szávai Ferenc
}

\begin{abstract}
A short-lived republic: December 5-6, 1918. A less known chapter of Hungarian historiography features the state-forming attempts taking place within the territory of the dualist state during 1918-1919. These failed as they were unable to gain international recognition, were poorly prepared, or their independence efforts did not prevail among opposing interests. One of these attempts was the Heinzenland/ Hoanznlaund Republic, existing for two days. This paper presents the very short history of the Republic of Heinzenland.
\end{abstract}

Keywords Great War (1914-1918), history of Central-Europe, History of Hungary, birth of the first Austrian Republic, history of Republic of Heinzenland, Vienna

\section{Bevezetés}

Az Osztrák-Magyar Monarchia területén több nagyobb és több kisebb államalakítási (mini államok) kezdeményezés indult el a bomlás folyamatában, hiszen a területi hovatartozás véglegesítése csak a békeszerződésekben került rögzítésre. Érdekes és érdemes megvizsgálnunk, hogy mi motiválta az adott nemzeteket/közösségeket az önállóságuk kimondására, a nagy egészből történő kiszakadásra. Születésük abba a történelmi tendenciába simul bele, amelyet a magyar társadalom Trianon kapcsán keserü tapasztalatként élt meg, s amely egész Köztes-Európában érvényesült: az első világháborút követően minden nemzetnek akkora államtere volt, amekkorát képes volt saját magának kiharcolni. ${ }^{1}$

A Nagy Háború végén egy korábban nyilván elképzelhetetlen, a kisközösségek természetes önvédelmi reflexeiből eredő jelenség is kibontakozott: a mini államok sorának megszületése a Kárpát-medencében. Hét ilyen mini államról, vagy más néven ideiglenes államtérről tudunk a magyar Szent Korona országainak területén:

\footnotetext{
* Intézmény: Kaposvári Egyetem Email: szavai.ferenc@ke.hu

${ }^{1}$ Nagy Miklós Mihály 2004, 221.
} 
- Bánáti Köztársaság: 1918. november $1-25 .^{2}$

- Vendvidéki Köztársaság: 1919. május 29.-június 6. ${ }^{3}$

- Szlovák Tanácsköztársaság: 1919. június 16.-július $7 .^{4}$

- Fiumei Szabadállam: 1920. november 12.-1924. március $26 .^{5}$

- Baranya-Bajai Szerb-Magyar Köztársaság: 1921. augusztus 14.-augusztus $21{ }^{6}$

- Lajtabánság: 1921. október 4.--november $5 .^{7}$

- Hiénc Köztársaság: 1918. december 5-6.

Ezekröl a kísérletekröl meglehetősen hiányosak és olykor meglepően pontatlanok az ismereteink ahogy ez jelen tanulmány témájánál a Hiénc Köztársaság esetében is rögzíthetö.

\section{A háttér: Német-Ausztria születése}

Az Osztrák-Magyar Monarchia - felbomlását követően - területén három önálló állam alakult: az Osztrák Köztársaság, a Magyar Királyság és a Csehszlovák Köztársaság. A volt osztrák tartományok közül Dalmácia, Szlovénia, valamint Bosznia-Hercegovina az új délszláv államhoz került (Szerb-Horvát-Szlovén Királyság). Ez utóbbi államba olvadt bele Horvátország és a Vajdaság, valamint Montenegró.

Románia a térségben a legnagyobb területeket kapta meg, elsőként Erdélyt, a partiumi területeket, valamint Bukovina egy részét az osztrák tartományokból. Az Osztrák-Magyar Monarchia területének egy részét (Galícia és Bukovina egyes területeit) foglalta magába az új Lengyel Királyság. A hatalmas területi átrendeződés kiegészült még az Olaszország és Görögország javára történő kisebb területi átrendeződésekkel. ${ }^{8}$

Tanulmányunk szempontjából az Osztrák Köztársaság születése fontos: 1918. november 11-én Károly császár nyilatkozatot adott ki, amelyben előre elismerte azt a döntést, melyet Német-Ausztria, a saját jövendő államformájára nézve hoz. NémetAusztria Államtanácsa 1918. november 11-én a demokratikus köztársasági államforma mellett döntött. ${ }^{9}$ Az így megszülető Osztrák Köztársaság az osztrák jogi felfogásban az államok sorában új jelenség volt, nem folytatása az Osztrák-Magyar Monarchiának. ${ }^{10}$

\section{A nyugat-magyarországi helyzet 1918 őszén}

A hazatérő katonák, a fegyverek, az élelmiszer- és szénhiány, a bizonytalan területi birtoklás, Nyugat-Magyarország nemzetiségi összetétele sajátos helyzetet teremtett a térségben. Itt jelentős számban éltek németek, akikre potenciális szövetségesként gondolhatott az új osztrák állam. Mivel a határok kérdése még képlékeny volt jó eszköznek bizonyulhatott az önálló állam megalakítására a nemzeti önrendelkezés teóriája.

\footnotetext{
${ }^{2}$ Gulyás László 2012/a, 89-108.

${ }^{3}$ Göncz László 2001.

${ }^{4}$ Gulyás László 2008/a, 134-143.; Gulyás László 2008/b, 143-153.

${ }^{5}$ Gulyás László-Bali Lóránt 2011, 143-150.; Gulyás László-Bali Lóránt 2012/b, 41-53.

${ }^{6}$ Gulyás László 2016, 105-112.

${ }^{7}$ Gulyás László 2012/c, 114-118.

${ }^{8}$ Berend T. Iván-Ránki György 1976, 255-258.

${ }^{9}$ Brauneder, Wilhelm 1998, 168-169.

${ }^{10}$ Uö. 189.
} 
A Hiénc Köztársaság megszületését az új Ausztria formálódásával kapcsolhatjuk össze. A Nyugat-Magyarországon élő hiencek a Vas, Sopron és Moson vármegyék németnyelvü lakosságát jelentették, feltételezések szerint mintegy 300000 lakost, akiknek zöme 125000 fö Vas vármegye területén élt. Főleg a kőszegi, felsőőri, körmendi, németújvári és a szentgotthárdi járásban éltek. ${ }^{11}$

A nyugat-magyarországi területsáv Ausztriához csatolásának ötlete Bécsben született meg, 1906-ban Josef Patry brossurát készített a témáról. Ennek megfelelően egyesületet is alapított Bécsben, de erre a területre a hatása kis mértékünek volt nevezhető. „Nyugat-Magyarországot Németausztriához!” A bécsi Alldeutsche Tagblattban e címen közölt cikkében Patry kijelentette: 112 ezer négyzetkilométert, 878582 lakost kér Ausztriának. Cserét ajánlott fel Magyarországnak - BoszniaHercegovina és Dalmácia lett volna az ellentétel. A régióban élö német népcsoport, a hiencek nevéből megalkotta az új német-osztrák tartomány nevét: Hienzenlandot. Ugyanakkor több szinten, de már az első világháború előtt benne volt a levegőben Nyugat-Magyarország elcsatolásának gondolata. ${ }^{12}$

Az ideiglenes osztrák nemzetgyülés 1918. november 22-én proklamálta igényét a németlakta nyugat-magyar területekre. Indoklásul felhozta, hogy ezek a területek nélkülözhetetlenek Bécs közellátása érdekében.

A Karl Renner vezette osztrák Államtanács 1918. november 17-én hivatalosan bejelentette igényét Magyarország nyugati területeire. Az osztrák fél mindezt plebiszcitum (népszavazás) keretében, a wilsoni 14 pontnak megfelelően képzelte megszerezni. Nemcsak a propaganda, hanem a német-osztrák ideiglenes nemzetgyülés is törvényjavaslatot készített elö, a velük határos magyar területek megszerzéséről. ${ }^{13}$

\section{A Hiénc Köztársaság kikiáltása}

Az osztrák irredenta mozgalom nem állt meg csak három vármegye megszerzésénél: Moson, Sopron és Vas vármegyére, hanem kiterjesztette elképzeléseit Zala és Pozsony vármegye egy részére is. $\mathrm{Az} 1918$ november közepén megfogalmazott területi követelések nemcsak a propaganda területén nyilvánultak meg, hanem megnyilvánultak abban is, hogy a hivatalos osztrák Államtanács által tett területi igény bejelentése és az Állam-nyilatkozat ${ }^{14}$ előtt Bécsben létrehozták a Westungarische Kanzlei-t, a NyugatMagyarországi Hivatalt. Ennek feladata a szabadcsapatok megszervezése volt, hogy elfoglalják az elcsatolni kívánt magyar területeket.

Ez feltehetően azonos volt a Nyugat-Magyarországi Ügyosztály intézményével, amelynek feladata a megszállás és a közigazgatás megteremtése volt. Ennek katonai vezetője Arnold Weigert százados volt, aki megtámadta Németújvárt, s úgy akarta elfoglalni, hogy kikiáltsa a Heanzenland (Hienzenland) Köztársaságot, ami később kimondta volna csatlakozását Ausztriához. Az ügyosztály vezérkara végül úgy döntött, hogy a katonai támadást Sopron irányába kell megindítani, mert ezt a várost szemelték ki a Hienzenland székhelyének. ${ }^{15}$

\footnotetext{
${ }^{11}$ Brenner Vilmos 1998/a; Brenner Vilmos 1998/b.

12 Kolnhofer Vince 2008, 4. Lásd még Tóth Imre 2006.

${ }^{13}$ Botlik József 2012, 18-19. Ez a népszavazás végül Sopron és környéke hovatartozásának eldöntésekor bekövetkezett.

${ }^{14} \mathrm{Az}$ Államtanács november 14-itörvényjavaslata a „Német-Ausztria területének terjedelméről, határairól és viszonyairól."

${ }^{15}$ Botlik József 2012, 22-23.
} 
November utolsó napjaiban alsó-ausztriai kaszárnyákban Dr. Albert Ritter hadnagy vezetésével leszerelt tisztek, kiknek kevés ismerete volt a nyugat-magyarországi helyzetről, fegyvereket gyüjtöttek a nyugat-magyarországi felkelök részére. December 5én reggel teherautókon több csoportban átszállították a határon, hogy a gyengén felfegyverzett helyi nemzetőrségeknek és polgárőrségeknek, akiknek az új köztársaság néphadseregévé kellett volna alakulnia, átadják. Felhívást is vittek Hienzenland kikiáltásáról. A felhívás utalt a nemzetek önrendelkezési jogára, a wilsoni pontokra, a kétmillió magyarországi németre és a 309 nyugat-magyarországi falura, melyek elzárásra kerültek a német nyelvi határoktól. Számos településen, sok ember kész volt az együttmüködésre, de rosszul voltak informálva és nem kaptak konkrét utasításokat. Nem szállták meg a vasútállomásokat, telefonközpontokat, postákat, így a magyar nemzetiségü hivatalnokok meg tudták akadályozni, hogy összeköttetés jöjjön létre az egyes települések között, és a magyar hatóságok rögtön ellenlépéseket is tudtak tenni. ${ }^{16}$

A fegyverszállítmányok egy kivételével nem értek célba. Lajtaújfalunál és Királyhidánál a magyar hatóságok kezébe kerültek, a Kabold felé tartót még Schwarzenbachnál az osztrák csendőrség tartóztatta fel. A legnagyobb szállítmány Sopron felé tartott, útközben néhány településen beszédeket tartottak és fegyvereket osztottak, emiatt későn érkezett Nagymartonba. A környező településekre agitátorokat küldtek és a soproni bevonulást másnapra tervezték. A megszakadt telefonösszeköttetés miatt nem tudták, hogy a többi településen nem sikerült az akció. ${ }^{17}$

Eredetileg Sopronba tervezték kikiáltani a köztársaságot, végül 1918. december 6-án este Nagymarton járási székhelyen kiáltották ki a Hienzenland Köztársaságot, amelyröl a rossz telefonvonalak miatt a legtöbb helyen nem is értesültek. Az új köztársaság kikiáltása érintette mind a 309 nyugat-magyarországi községet, felvetette a Republik Hienzenland Anschluss lehetöségét az akkori Ausztriához, kimondta az ideiglenes hiénc köztársasági kormányzat létrehozását Sopronban és rendelkezett a Hienzenland Köztársaság nemzetgyülési választásáról. ${ }^{18}$

\section{A Hiénc Köztársaság bukása}

Nem sokat kellett várni a magyar ellenválaszra. Sopronban riadóegységeket hoztak létre, honvédekből, nemzeti gárdistákból és pályaudvari őrségből és még aznap december 6-án éjjel páncélvonattal magyar csapatok indultak Nagymartonba. Hajnalra körbevették a települést. A túlerő láttán a helyi német nemzetiségű magyar állampolgárokból álló, osztrákpárti nemzetőrség ellenállás nélkül letette a fegyvert. Az osztrák tiszteknek sikerült elmenekülniük, a helyi vezetőket örizetbe vették, ügyükben bűnvádi eljárást indítottak, de a Károlyi-kormány utasítására közkegyelmet kaptak. A fegyveres betörésnek egy áldozata volt, Franz Temmer hadnagy, aki Győrben néhány hét múlva, valószínüleg sebesülésébe belehalt. Ö az egyetlen áldozata a „Hienzenland Köztársaság” kalandnak.

Vas megyébe is terveztek betörést Stájerországból, de ez időben nem volt összehangolva az északival. A nagymartoni események hallatán az akcióról lemondtak. Az osztrák Államtanács hivatalosan tagadta, hogy köze lenne a nyugat-magyarországi osztrák betöréshez, valamint „Heanzenland” kikiáltásához, és a katonai támadást ismét

\footnotetext{
${ }^{16}$ Kolnhofer Vince 2008, 38-39.

${ }^{17}$ Uö. 39.

${ }^{18}$ Gerald Schlag 2001, 136-139.
} 
felelőtlen egyéni túlkapásnak minősítette. ${ }^{19}$ A bécsi újságok december 7-én, feltehetően az előzőleg megkapott felhívások alapján, Heinzenland kikiáltásáról tudósítottak. Ezt a tényt Magyarország fel tudta használni az Ausztria elleni támadásra. A kormány tiltakozott Hans Cnoblochnál a fegyveres határsértés miatt. Otto Bauer osztrák külügyi államtitkár szerint a kivitelezés dilettantizmusa miatt bukott el a terv és ezzel veszélyeztették a Magyarországról érkező élelmiszerszállítmányokat. ${ }^{20}$ Wiener Neustadt polgármestere Anton Ofenböck elhatárolódott a kísérlettől. Maga Josef Suchard a Nagymartoni népi tanács elnöke és az ottani nemzeti gárda parancsnoka véletlennek nevezte a fogságba esésüket.

\section{Konklúziók}

Nem lehet tudni, hogy valójában kitől származott a bécsi német nacionalista körökben megszületett önálló köztársaság (Hienzenland) ötlete. Raimund Neunteufel és a Westungarische Kanzlei nevü szervezet, továbbá a Verein zur Erhaltung des Deutschtums in Ungarn tagjai és néhány Alsó-Ausztria déli részéről származó szociáldemokrata játszott szerepet benne. ${ }^{21}$ Később letagadták ezt, és a bizonyítékokat igyekeztek megsemmisíteni. Bizonyos, hogy a terv kiötlői kevés megbízható információval rendelkeztek a térségről. A vágyaikra és hallomásokra támaszkodtak, és kevés politikai tapasztalattal rendelkeztek. A propagandaanyagokat bizalmi embereik útján terjesztették a falvakban.

Az akció bukása után vált ismertté, hogy szerepe volt Viktor Käfter nagymartoni munkásvezetőnek és a szociáldemokrata testvérpárnak Josef és Hans Suchard-nak is. Magyar források szerint Arnold Weigert százados volt a kulcsszereplő, aki a Westungarische Kanzlei katonai osztályát vezette. Szabadcsapataival Fürstenfelből Güssingbe tört, azzal a céllal, hogy kikiáltsa a Heinzenland Köztársaságot, majd a következő lépésben Ausztriához csatlakozzon. Az új köztársaság központjául Sopront akarta, azt remélte, hogy a környező falvak németajkú lakossága nagy egyetértéssel támogatja öt. A tervet végtelen optimizmus és naivizmus jellemezte, azt hitték, hogy az Egyesült Államok által hirdetett önrendelkezési jog érvényesülhet, illetve a demokratikus népmozgalom spontán módon és rögtön elfogadásra kerül, és élvezi egyben a védelmet. A sajtó és a propaganda segítségével a nyilatkozatot széles körben ismertették, az „éjszaka és a köd” leple alatt agitátorok felhasználásával készítették elö.

Mindenesetre az alig 24 órás történet rámutatott arra a tényre, hogy Budapestnek valamit kezdenie kellett a nyugat-magyarországi helyzettel. A kiszakadási törekvés veszélyes folyamatokat indíthatott volna el. Mindemellett komoly tanulság volt az is, hogy mielöbb kezdjék el a földek újbóli felosztását is. ${ }^{22}$

A magyar kormány 1919. január 29-én határozott arról, hogy önrendelkezési jogot ad a terület német lakosságának. A VI. számú néptörvény értelmében a Magyarországon élő német ajkú magyar állampolgárok egységes nemzetet alkotnak, autonóm jogterületet képeznek. ${ }^{23}$

\footnotetext{
${ }^{19}$ Botlik József 2012, 27-28.

${ }^{20}$ Kolnhofer Vince 2008, 39-40.

${ }^{21}$ Hans Suchard 1893-1968. Osztrák szakszervezeti titkár és politikus. A Burgenlandi Tartományi Tanács képviselöje. testvérével megszervezte Sopronban a Republik Heinzenlandot, majd fogságba került és a Károlyi kormány amnesztiájával szabadult 1918. december 26-án. Újságíró és tartományi képviselö, szociáldemokrata politikus.

${ }^{22}$ Uö. $139-145$.

${ }^{23}$ Tóth Imre 2006, 42-43.
} 
A nyugat-magyarországi terület hovatartozásának kérdése és ügye sokáig nem szerepelt a béke előkészítés tematikájában, végül az osztrák békeszerződésben (SaintGermain-en Laye) 1919. szeptember 10-én dőlt el Ausztria javára, majd a soproni népszavazás ezt módosította 1921. december 14-16 között és tett rá pontot.

\section{Felhasznált irodalom}

Bachinger Karl T. 1981, Umbruch und Desintegration nach dem Ersten Weltkrieg. Österreichische wirtschaftliche und soziale Ausgangssituation in ihren Folgewirkungen auf die Erste Republik. Habilitationsschrift der Wirtschaftsuniversität, Wien 139-144. old.

Berend T. Iván-Ránki György 1976, Közép-Kelet-Európa gazdasági fejlődése a 19-20. században. 2. kiadás. Budapest.

Botlik József 2012, Nyugat-Magyarország sorsa 1918-1921. Vasszilvágy: Magyar Nyugat Könyvkiadó.

Brauneder, Wilhelm 1998, Österreichische Verfassungsgeschichte. 7. Auflage. Wien.

Brenner Vilmos 1998/a, A hiénc néptörzs egykor és ma. Vasi Szemle, 1998. LII. évfolyam 5. szám. I. rész.

Brenner Vilmos 1998/b, A hiénc néptörzs egykor és ma. Vasi Szemle, 1998. LII. évfolyam 6. szám. II. rész.

Göncz László 2001, A muravidéki magyarság 1918-1941. Lendva.

Gulyás László 2008/a, Edvard Beneš. Közép-Európa koncepciók és a valóság. Máriabesnyő-Gödöllő: Attraktor Kiadó.

Gulyás László 2008/b, Beneš statesman or charlatan? The plans and the reality 19081948. Toronto-Buffalo: Corvinus Publishing.

Gulyás László 2012/a, A Délvidék története 2. A török kiüzésétől Trianonig 1683-1920. Közép-Európai Monográfiák 6. Egyesület Közép-Európa Kutatására. Szeged.

Gulyás László 2012/b, A Horthy-korszak külpolitikája 1. Az első évek 1919-1924. Máriabesnyő: Attraktor Kiadó. 114-118. old.

Gulyás László 2016, A Baranyai Szerb-Magyar Köztársaság. Zombori István szerk. A szerbek Magyarországon 1918-1921. Budapest. Magyar Egyháztörténeti Enciklopédia Munkaközösség. 105-112. old.

Gulyás László-Bali Lóránt 2011, The Fiume question 1918-1920. Öt Kontinens. 2011/1. szám ELTE. Budapest. 143-150. old.

Gulyás László-Bali Lóránt 2012/b, Ten years from the history of Fiume, 1914-1924. 4153. pp. The Twentieth Century. 2012/2.

Kolnhofer Vince 2008, A gradistyei horvátok és a magyar-osztrák határkijelölés. PhDdisszertáció. Pécs.

Nagy Miklós Mihály 2004, Magyarország hadtörténeti földrajza (A magyar hadtörténelem földrajzi alapjai) PhD-disszertáció. Pécs.

Ormos Mária 1984, Padovától Trianonig. 1918-1920. Budapest: Kossuth Könyvkiadó.

Schlag Gerald 2001, Aus Trümmern geboren... Burgenland 1918-1921. Eisenstadt.

Tóth Imre 2006, A nyugat-magyarországi kérdés 1922-1939 - Diplomácia és helyi politika a két világháború között. Doktori disszertáció. Sopron. 